UDC 788.6

DOI $10.33287 / 222005$

Hromchenko Valerii, PhD., Associate Professor, Vice-rector of scientific work M. Glinka Dnepropetrovsk Academy of Music tel. (097) 470 - 23 - 10 e-mail: gromchencko.valeriy@gmail.com

Gorban Andriy, Master of the Department of „,Orchestral Instruments" M. Glinka Dnepropetrovsk Academy of Music tel. (097) 145 - 12 - 01 e-mail: clarinet-and-sax@ukr.net

\title{
PERFORMANCE-STYLE FEATURES OF THE CONCERTO № 3 FOR CLARINET AND ORCHESTRA BY L. SPOHR
}

The purpose of this scientific investigation is the disclosure of the creative phenomenon of German composer L. Spohr in wind contemporary academic music and performing art by identifying the most characteristic performance and the stylistic peculiarities of creator that is instrumentally artistic speech. The material of this study is the well-known Concerto № 3 for Clarinet with symphonic orchestra by L. Spohr. The methods of this scientific intelligence are in the application of general scientific approaches to the study of a particular topic. The historical method is used to highlight the place of clarinet masterpieces and, in particular, Concert № 3, in the palette of the artist’s creative achievements. The comparative method creates the possibility of comparing a number of clarinet means of expression with the artistic potential of string-bow performance. The sequence of presentation of the material is determined by the action of the structural-analytical method. Methods of observation and generalization are of practical importance. The scientific novelty of this specialized disquisition is due to the insufficient study of the clarinet works of L. Spohr in the light of modern musicological thought. Conclusions. The distinctiveness of L. Spohr's performance- stylistic peculiaritics of instrumental speech in 
clarinet Concerto № 3 for clarinet and orchestra is marked, first of all, by the use of various types of virtuosity (shallow, combined, large virtuosity), the performance of various types of melismatics both in slow and melodic ways, the use of high and ultra-high sound registers of the instrument (note to the fourth octave), which, we emphasize, comes from the violin academic artistic and creative activity of L. Spohr and, in general, and of high performing skill as a virtuoso violinist.

The key words: L. Spohr, Concerto, clarinet, orchestra, performance, virtuosity, creativity.

\section{Громченко Валерій Васильович, кандидат} мистецтвознавства, доцент, проректор 3 наукової роботи Дніпропетровської академії музики ім. М. Глінки

Горбань Андрій Володимирович, магістрант кафедри „Оркестрові інструменти” Дніпропетровської академії музики ім. М. Глінки

Виконавсько-стильові особливості Концерту № 3 для кларнета $з$ оркестром Л. Шпора

Мета статті - розкриття творчого феномену знаного німецького композитора, скрипаля, викладача Л. Шпора у сучасному духовому академічному музично-виконавському мистецтві, шляхом виявлення найбільш характерних, оригінальносвоєрідних інструментального виконавсько-стильових особливостей дослідження постає Концерт № 3 для кларнета 3 оркестром Л. Шпора. Методи пропонованої наукової розвідки полягають у застосуванні загальнонаукових підходів до вивчення означеної теми. Використовується історичний метод, за допомогою якого висвітлюється місце кларнетових шедеврів та, зокрема Концерту № 3, у палітрі творчого доробку митця. Порівняльний метод утворює можливість співставлення низки кларнетових засобів виразності 3 художнім потенціалом академічного струнносмичкового виконавства. Послідовність викладення матеріалу зумовлюється дією структурно-аналітичного методу. Практичного значення у роботі набувають методи спостереження та узагальнення. Наукова новизна дослідження зумовлюється недостатньою вивченістю кларнетових творів Л. Шпора у світлі сучасної музикознавчої думки, наголосимо, як у призмі вітчизняної, так і в лоні зарубіжної дослідницько-наукової сфери. 
Висновки. Яскраво-оригінальна самобутність виконавськостильових особливостей інструментального мовлення Л. Шпора у Концерті № 3 для кларнета 3 оркестром позначається, насамперед, використанням різноманітних типів віртуозності (мілка, комбінована, крупна віртуозність), виконанням багатоманітних видів мелізматики як у повільних, так і в стрімких мелодичних побудовах; застосуванням високого та надвисокого регістрів звучання інструмента (нота до четвертої октави), що, підкреслимо, походить від скрипкової академічної художньо-творчої активності Л. Шпора та, зокрема, його високої виконавської професійної майстерності як видатного скрипаля-віртуоза.

Ключові слова: Л. Шпор, Концерт, кларнет, оркестр, виконавство, віртуозність, творчість.

Громченко Валерий Васильевич, кандидат искусствоведения, доцент, проректор по научной работе Днепропетровской академии музыки им. М. Глинки

Горбань Андрей Владимирович, магистрант кафедры „Оркестровые инструменты” Днепропетровской академии музыки им. М. Глинки

\section{Исполнительско-стилевые особенности Концерта № 3 для кларнета с оркестром Л. Шпора}

Цель статьи - раскрытие творческого феномена известного немецкого композитора, скрипача, педагога Л. Шпора в современном духовом академическом музыкальноисполнительском искусстве, путем выявления наиболее характерных исполнительско-стилевых особенностей инструментального творчества композитора. Материалом исследования является Концерт № 3 для кларнета с симфоническим оркестром Л. Шпора. Круг методов исследования заключается в применении общенаучных подходов к изучению отмеченной темы. Используется исторический метод, с помощью которого показывается место кларнетовых шедевров и, в частности Концерта № 3, в палитре творческого наследия мастера. Сравнительный метод образует возможность сопоставления ряда кларнетовых средств выразительности с художественным потенциалом академического струнно-смычкового исполнительства. Последовательность изложения материала предопределяется действием структурно-аналитического метода. Практическое 
значение в работе приобретают методы наблюдения и обобщения. Научная новизна представленного исследования формируется недостаточной изученностью кларнетовых произведений Л. Шпора в свете современной музыковедческой мысли. Выводы. Яркая самобытность, оригинальность исполнительско-стилевых особенностей инструментального почерка Л. Шпора в Концерте № 3 для кларнета с оркестром обозначается, в первую очередь, использованием разнообразных типов виртуозности (мелкая, комбинированная, крупная виртуозность), применением различных видов мелизматики как в медленных, так и в стремительных мелодических построениях; внедрением высокого и сверхвысокого регистров звучания инструмента (нота до четвёртой октавы), что, подчеркнём, берёт начало от скрипичной академической художественно-творческой активности Л. Шпора и, в особенности, его высокого профессионального исполнительского мастерства как выдающегося скрипача-виртуоза.

Ключевые слова: Л. Шпор, Концерт, кларнет, оркестр, исполнительство, виртуозность, творчество.

Formulation of the problem. Accentuate, that for the romantic era, the characteristic feature is the image of a romantic hero with all the contradictions of his character. Programming prevails in music, there is an increased interest in national culture, historical past, folk songs, legends. In the $19^{\text {th }}$ century, European romantic composers reached new heights in harmony, instrumentation and musical form, forming the classical composition of the orchestra, already having a full band of wind instruments. Romantic composers create new vibrant sound colors, and the timbre dramaturgy becomes more important in orchestral sound as a result of mixing different sound timbres. Interesting orchestras, opera and choral ensembles are appearing at the time, and with them are outstanding conductors, vocalists and instrumentalists. In Western Europe, there is a new flowering of musical creativity associated with a high level of performing culture. At the beginning of the $19^{\text {th }}$ century, the creative take off began, gained the professional authority of the eminent German violinist L. Spohr (1784 - 1859), who succeeded in various fields of creative activity a namely performing, composing, pedagogical, established in those days as a brilliant soloist, virtuoso virtuoso, virtuoso also conductor. It is this professional versatility that makes L. Spohr stand out from among the other now- 
unknown composers of the nineteenth century, and consequently to actualize research on many issues related to the name of this master of romance.

Relevance of research. Concerns for clarinet with orchestra remain on a number of issues that have not been studied in relation to Spohrs' creative work. In total, the composer created four clarinet masterpieces of the genre. It should be emphasized that the artistic, cultural, educational, pedagogical, performing value of these works has not lost weight in our time, but in the light of modern musicology, to a great extent, the clarinet works identified still remain unexplored. The periods of the development of musical art, which are at the intersection of the eras of classicism and romanticism, unfortunately, are little studied by musicologists.

Literature review. The theoretical basis of the study was formed by the scientific works of famous musicians-teachers and performers on wind academic instruments: D. Zlotnikov [1], N. Solovyov [2], Johnston Stephen Keith [5] where the development and formation, performing peculiarity of clarinetists-performers of the Romantic era but, unfortunately, the works of L. Spor, written for clarinet, are poorly researched and insufficiently covered by theorists.

The purpose of this represented scientific article is to reveal the creative phenomenon of L. Spohr in contemporary wind academic music-performing arts, by identifying the most characteristic performance and stylistic features, certain characteristic features of the clarinet writing, speaking, in other words, the writing of Ludwig Spohr in light of Concerto № 3 for clarinet with orchestra, as one of the most performed of the four clarinet masterpieces of German romance.

The object of study is wind academic musical and performing arts of the $19^{\text {th }}$ Century, the subject of the performance and style features of Concerto № 3 for clarinet with orchestra by L. Spohr.

Presenting main material. Already from the first complete acquaintance with the concert one can see in the absence of such familiar pauses for the musicians, the corresponding orchestral fragments of the final or connective value, in which, along with the soloist's physical rest, the orchestral competitiveness and natural agonality of the orchestral accompaniment is affirmed. The clarinet party immediately embarks on the signs as physically heavy and, to some extent, not traditional for solo brass performance accompanied by the orchestra. 
Concerto № 3 for clarinet with the orchestra by L. Spohr is based on a traditional classical form, consists of three parts contrasting with each other - Allegro moderato - Adagio - Vivace non troppo. At the center of the artistic content of Concerto № 3 for the clarinet with the orchestra by Ludwig Spohr is a romantic hero whose drama of relationships with the fact of life, a world of ebullient feelings, events and related circumstances, forms an extremely uncluttered, exceptionally colorful, emotionally-sensuous clarinet masterpiece, namely, heroic, life-affirming emotionality in the first part of the work, lyrically-lamentous, cantilenic in the second, active-fiery and utterly frank instrumental sensuality in the third part of the concert.

Form of the first part of the concert - Sonata Allegro has double exposure: the first exposure is orchestra; the second exposure is a solo. The energy, confidence and cheerfulness of the general nature of the music of the exposition are emphasized by the active rhythmic pulsation, virtuosity, thematic relief.

Almost from the beginning, the soloist's playing is full of extremely virtuoso passages, and in general, complex performance and artistic tasks, namely a variety of trills, interval jumps on short durations, a wealth of small passages, frequent changes of strokes with the predominance of preyalance of combined streak constructions.

It deserves special attention the phrase-elongated fine virtuosofinger technique along with it, the motive-local large virtuosity (artisticcontent climaxes, cadences), as well as the extremely colorful melismatics, both in slow and rapid melodic constructions (trills, mordents, the group). The big phrases are fraught with technical challange, so it is very difficult for a clarinet performer to maintain that kind of virtuosity in one breath.

Content-extensive phrasing with the extension of the melodic line to eight beats and more, again leads to the maximum activation of the technique of performing breathing musician of brass section. The respiratory system is also activated when using the treble of clarinet sound. The romantic immensity, the infinity of the emotional-sensual palette of the clarinet masterpiece, leads to the approval of the so-called four-octave working range of instrumentalist.

The second part of the Adagio concert is a timbrely breakdown, vocally interpreted instrumentality. The phrase-lengthened principle of constructing a melodic line that is maximally filled with melismatic figures in the climax fragments of musical sentences is preserved. 
Exactly here there is an elegiac, sentimental image associated with the lyrical intonation of the song-romance type. In one of the youth articles dated 1828 , R. Schuman said: „If flowers and dew were able to speak, then they would probably do it the way you sing; you are a dewmoistened night violet ..." $[3,162]$.

The calm, expressively sustained melody of the music sets the task for the performer - to be able to „sing” on the instrument and, of course, to possess the stroke of legato and legatissimo.

The use of the first and small octaves in the artistic-logical, sensually-aesthetic deployment of melodic constructions determines the priority of timbre-dynamic, colorful means of expression.

The third part of the clarinet masterpiece - concert № 3 by L. Spohr (Vivace non troppo) is perhaps the most focused complexity of the whole cycle. The character is extremely danceable, bright. Two sections, each consists of two themes, are distributed by the Tutti Orchestra. The concentration of various types of virtuosity combined with the versatility of dynamic types (contrasting, gradually increasing and decreasing types) form the phenomenon of „cantilan virtuosity”, which in the romantic performing style imposes the highest technological requirements on the soloist musician.

Each section consists of two topics, between which the Tutti Orchestra sounds. After a three-beat introduction, the first clarinet solo with a light waltz theme is heard and is repeated an octave below. By the end of the first section, the „virtuoso passages of the triol” are brought to end, which ends with the gentle character of the second theme.

At the beginning of the second section after the Tutti Orchestra the clarinet solo sounds again the first theme, at the end of which the major is changed by a minor of the same name. Then, after the Tutti orchestra, a second theme solo is heard. Virtuoso trio passages complete the second section of part III of the concert. The finale of the work is outlined by a fast code. The last chords of the orchestra, reinforced by the timpani, sound on ff. In the solo in the five heartbeats ,g" 3 octaves with the dynamic growth of sonority. The last are the energetic sounds of ,g” on ff, which sound in the first and small octaves.

In the finale of the concert many virtuosic fragments with high technical complexity of the clarinet party. Also, the composer used various bar combinations (alternation of legato and staccato strokes) in this part and applied the techniques of increasing or damping the dynamics on the sustained sounds. 
Thus, phrase-elongated fine virtuoso-finger technique, motivelocal coarse virtuosity (climaxes, cadences), extremely colorful melismatics both in slow and rapid melodic constructions (trills, mordents, group), content-decomposition phrasing with elongation lines of up to eight beats, as well as the use of the treble clarinet sound (note to fourth octave), come primarily from the violin artist's creative consciousness, the great performing practice of L. Spohrs in playing the violin and, in general, determine the main compositional and stylistic originality corresponding significance of character, steady distillation of author L. Spohr writing, particularly his masterpieces clarinet a namely, the third concert for clarinet with orchestra.

Undoubtedly, the artistic and creative realization of the artistic potential of the german master-romantic would not be possible without the creative alliance of L. Spohr with a famous clarinetist - soloist in those days Johann Simon Hermstedt, which at a high professional level artistically presented that is the nature of the solo clarinet, which, we emphasize, from the first victorious steps of Wolfgang Mozart (a major-clarinet concert) and masterpieces by the first romantic-spiritualist Karl Maria Weber, was asserted by a great solo potential, brilliantly emphasized and fully augmented by Ludwig Spohr.

D. Zlotnikov in his work ,Concerts for Clarinet with Orchestra by L. Spohr and K.M. Weber - similarities and differences” writes: „Both composers use the full range of the instrument (from a small octave to a fourth), slightly exceeding the traditionally used working range of the clarinet. But if K.M. Weber uses the extremely high notes of the instrument once (in the finals of part I of the First Concert), then L. Spohr applies them in almost every part of all concerts. He uses this sound both in ascending passages and in fast changing intervals, which is quite difficult to perform, even on modern clarinets. The use of L. Spohr upper case instrument contrasts the solo party against the background of the orchestra, the passages sound easier, but it also creates appropriate difficulties for the performer" $[1,5]$.

Conclusions. The above indicates that it was L. Spohr who founded a specific specific-defined textural-timbre complex of clarinet interpretation, which basically combines both virtuoso and all other expressive capabilities of the instrument, which is the perfection of the composer's skill in revealing his artistic uniqueness, solo distinctive differences from other academic wind instruments. 
Concerts for clarinet with orchestra by L. Spohr, in particular Concerto № 3, are extremely popular, albeit extremely rare, to say the least, original artistic achievement in contemporary concert, pedagogical, cultural, educational, artistic. Their performative interpretation goes back to polar different versions of artistic and creative interpretation, but it is emphasized that this is the enduring uniqueness of the composer-style phenomenon of the outstanding german violinist and composer of the era of musical romanticism L. Spohr.

Research prospects L. Spohr's creative phenomenon in the light of the clarinet music-performing arts is formed in the foreground of the deep study of the artist's artistic personality and the peculiarities of the instrumental speech of the artist, which is defined in his other clarinet masterpieces.

\section{Список використаних джерел і літератури:}

1. Злотников Д. Концерты для кларнета с оркестром Л. Шпора и К.М. Вебера сходства и различия. „Современные проблемы науки и образования”. 2014. № 4. URL: https://www.science-education.ru/ru/article/view?id=13423 (дата звернення 12.09.2019).

2. Соловйов Н.Ф. Шпор Людвіг. Енииклопедичний словник Брокгауза і Ефрона. T. 82. C. $189-190$.

3. Шуман Р. Про музыку и музыкантов: Т. 2. Москва : Музыка, 1979. 294 с.

4. Brown C. Louis Spohr: a Critical Biography. Cambridge, 1984. 364 p.

5. Keith J.S. The clarinet concerts of L. Spohr. Dissertation submitted to the Faculty of the Graduate School of the University of Maryland in partial fulfillment of the requirements for the degree of Doctor of Musical Arts. 1972. 147 p.

\section{References:}

1. Zlotnikov, D. (2014). Concerts for clarinet and orchestra L. Spurh and K.M. Weber similarities and differences. Sovremennye problemy nauki i obrazovanija, 4 Retrieved from https://www.science-education.ru/ru/article/view?id=13423 [in Russian].

2. Solovjov, N.F. (2002). Ludwig Spurh. Encyklopedychnyj slovnyk Brokghauza i Efrona, 82, 189-190 [in Ukrainian].

3. Shuman, R. About music and musicians. Moskva: Muzyka [in Russian].

4. Brown, C. (1984). Louis Spohr: a Critical Biography. Cambridge [in English].

5. Keith, J.S. (1972). The clarinet concerts of L. Spohr. Dissertation submitted to the Faculty of the Graduate School of the University of Maryland in partial fulfillment of the requirements for the degree of Doctor of Musical Arts [in English]. 